\title{
The Relationship between Work-life Balance Programs and Employee Satisfaction: Gender Differences in the Moderating Effect of Annual Income
}

\author{
Yutaka Ueda (Corresponding author) \\ Faculty of Economics, Seikei University \\ 3-3-1, Kichijoji-kitamachi, Musashino, Tokyo, Japan \\ Tel: 81-422-37-3589Ｅ-mail: ueda@econ.seikei.ac.jp
}

Received: April 25, 2012

Accepted: May 18, 2012

Online Published: June 30, 2012

doi:10.5430/jbar.v1n1p65

URL: http://dx.doi.org/10.5430/jbar.v1n1p65

\begin{abstract}
This article examines whether the comprehensiveness of work-life balance (WLB) programs influences employee satisfaction and whether this relationship is moderated by employee income. Using data collected from 2972 Japanese employees, the present study reveals a significant positive effect of WLB programs on satisfaction with job, employer, and WLB among male employees. However, there was a significant effect of WLB programs only on satisfaction with employer among female employees. Further, some of these relationships are found to be moderated by annual employee income, such that the effects of WLB program comprehensiveness are greater for higher-income employees than for lower-income employees.
\end{abstract}

Keywords: Work-life balance, Employee satisfaction, Income, Gender

\section{Introduction}

During the past quarter century, there has been a dramatic increase in the amount of research focusing on the balance between work and life for employees (Michel, Mitchelson, Kotrba, LeBreton, \& Baltes, 2009). Employees need to consider their work-life balance (WLB) in order to adequately distribute their physical and psychological energy to the areas of both work and life. Further, consideration of WLB is also important for employers because WLB can improve and influence attitudes toward the organization and employee behaviors (Baral \& Bhargava, 2010; Beauregard \& Henry, 2009; Hill, Ferris, \& Martinson, 2003). In fact, although Japan was once known as one of the most "workaholic" nations in the world (Dore, 1979-1980; Money \& Graham, 1999), Japanese companies have since instituted various WLB programs to allow their employees to fulfill their responsibilities in both the workplace and the family (Matsuda, Kokumai, \& Wang, 2009).

The objectives of WLB programs are to reduce the behavioral and psychological burdens on employees resulting from the competing norms and requirements of the domains of work and family; these objectives are intended to decrease the occupational stress resulting from work-family conflict and to foster feelings of happiness (Gropper, Gartke, \& MacLaren, 2010; Tytherleigh, 2003). Therefore, we can expect employees to feel more satisfaction with their work and family when they enjoy the benefits of WLB programs provided by their employers. However, the comprehensiveness of WLB programs in an organization does not necessarily predict employee satisfaction, because employee situations surrounding WLB programs also influence the relationships between WLB programs and employee satisfaction. This article examines whether annual income, as one variable associated with employee situations, moderates the effect of employer-sponsored WLB programs on employee satisfaction. Concretely, it aims to determine whether the evaluation of the same set of WLB programs differs according to gender and income using the data collected from 2972 Japanese employees.

\section{WLB and Satisfaction}

Company-sponsored WLB programs intended to improve employee WLB are expected to have a positive impact on employee feelings and attitudes and increase their general satisfaction. Yet, research to date has not always supported this assumption.

Some research has found a positive relationship between WLB programs and satisfaction. For example, Grandey, Cordeiro, and Michael (2007) found that company support of a work-family balance (family-supportive 
organizational perception) was strongly, negatively associated with work-family conflict and positively associated with job satisfaction. Moreover, this research also found that the number of hours worked moderated the relationship between organizational support and work-family conflict. Some researchers have focused on telecommuting as an important WLB program. Telecommuting also contributes to the life satisfaction of married females with school-aged children by enhancing their sense of balance between work and life and their perceived quality of life (Hilbrecht, Shaw, Johnson, \& Andrey, 2008).

In contrast to these results, some researchers have found that WLB programs are not always evaluated or received positively by companies and employees (Ciutacu, Chivu, and Hurley, 2008). For example, Cooke, Zeytinoglu, and Mann (2009) revealed that a weekend-based short workweek (WBSW) does not have a positive impact on employee job satisfaction. Smith and Garner (2007) further revealed that WLB initiatives by employers did not significantly reduce work-family conflict after correcting for other factors within the hierarchical regression. Further, Golden (2006) found that the relationship between the prevalence of telecommuting and job satisfaction was not linear but was instead mediated by leader-member exchange quality, team-member exchange quality, and work-family conflict. Bailey and Kurland (2002) stated, "there is little clear evidence of increased job satisfaction among teleworkers in the studies we examined" (p.389). Finally, in research focusing on Japanese workers, Fujimoto (2006) revealed that larger amounts of vacation time did not always satisfy more needs among Japanese employees. In fact, according to his survey, Japanese employees preferred working constantly without major career disruptions, and more than three-fourths of them did not want to take a vacation lasting more than one month.

\section{Incomes and WLB Programs}

Organizations provide various kinds of WLB programs to serve the different needs of their employees. If employees receive the benefits of a WLB program or know they can receive them whenever they need them, they feel more comfortable and optimistic about the future. In particular, employees generally are not aware of the types of WLB programs that will be necessary for them in the future, so WLB program comprehensiveness is considered to be predictive of employee attitudes towards life and work. In this context, WLB program comprehensiveness is defined as the degree to which the WLB programs offered by employers are varied and fulfilling. Concretely, we believe that if employees perceive WLB program comprehensiveness, they will be more satisfied with not only their WLB but also with their employer, because the comprehensiveness of a WLB program creates the perception of organizational support; such perceptions have been found to positively affect employee satisfaction as a result of social exchange (Lambert, 2000; Muse, Harris, Giles, \& Feild, 2008). Valcour, Ollier-Malaterre, Matz-Costa, Pitt-Catsouphes, and Brown (2011) found that employee perceptions of organizational work-life support were influenced by two mechanisms: signaling that the organization cares about their WLB and helping them develop the resources they need to integrate work and life roles. The former is considered to especially influence satisfaction with the employer, while the latter is more related to job satisfaction. Accordingly, we hypothesize the following:

H1: WLB program comprehensiveness will positively influence employee satisfaction with WLB, job, and employer.

We also believe that employee income will mediate the positive effect of WLB program comprehensiveness on employee satisfaction for the following reasons: first, company-sponsored WLB programs are not always accompanied by a guarantee of sufficient income. For example, although Japanese law states that, during childcare leave, employees have a legal right to receive half the wages they received before taking temporary childcare leave, these amounts are not necessarily sufficient for their families. Fujimoto (2006) inferred that Japanese employees dislike long vacations because they considered that long vacations would jeopardize the possibility of promotions and pay raises in the future. He observed that " $(t) h e$ respondents also tend to feel that they are responsible financially for their family, indicating that taking a long leave would make it more difficult to sustain their family life" (p.212). Therefore, the availability of WLB programs for employees is influenced not only by organizational factors (such as whether the employer actually provides these programs), but also by the employees' expectation that they will have sufficient income while utilizing WLB programs. In addition, even if WLB programs are recognized as a key piece of evidence that the employer supports its employees (Lambert, 2000; Muse et al., 2008), employees that do not receive enough money from their employers are less likely to recognize WLB program comprehensiveness as outweighing the benefits they would receive through social exchange between the employer and the employee. Employees who do not receive enough money may also be less satisfied with the employer. Therefore, we believe that employees' family income levels will moderate the relationship between WLB program comprehensiveness and employee satisfaction.

H2: Employee income will moderate the relationship between WLB program comprehensiveness and employee satisfaction, such that the effect of WLB program comprehensiveness on employee satisfaction will be stronger for 
employees with high income than for those with low income.

Figure 1 depicts our two hypotheses regarding the relationship between WLB program comprehensiveness, employee satisfaction, and income.

Insert Figure 1 about here

\section{Research Methods}

\subsection{Sample}

The data for this secondary analysis, "Current Situation, Problems, and Direction of Benefit Programs of Japanese Companies" by the Meiji Yasuda Institute of Life and Wellness, Inc. (MYILW), were provided by the Social Science Japan Data Archive, Center for Social Research and Data Archives, Institute of Social Science at the University of Tokyo. MYILW collected the data in December 2006 from full-time and part-time employees working in business organizations located in one of 16 large, representative cities (e.g., metropolitan Tokyo) in Japan. These employees were randomly sampled from those who were registered in the database of the online research company Macromill, categorized on the basis of the demographic distribution in Japan (stratified random sampling). The final sample size was 2972 employees. Among them, 1967 were full-time employees and 1005 were part-time employees.

\subsection{Measures}

WLB program comprehensiveness. The respondents were presented with 16 kinds of WLB programs and asked whether their organizations offered these. Of the 16, one WLB program was omitted because it was considered to be a type of workplace communication rather than a WLB program. The remaining fifteen programs were judged as representative WLB programs (see Table 1). The original binary responses ([0], the program is not offered [1], the program is offered) were aggregated into the WLB program comprehensiveness variable used in the present analysis. Larger values of WLB program comprehensiveness indicate that the employer has a more comprehensive WLB program for its employees.

Annual income. Annual income was examined as a control variable to examine the effect of WLB program comprehensiveness and as a moderator of the relationship between WLB program comprehensiveness and employee satisfaction. Respondents were asked to provide their approximate real annual income (in units of 1000000 Japanese yen) in the year before survey; this amount was used as the income variable.

Satisfaction. Employees' satisfaction was measured with three independent items to indicate the degree to which respondents were satisfied with WLB programs, their jobs, and their employers. The items included questions such as, "Are you satisfied with your current (WLB, job, or employer for which you are working)?" Each item used a 5-point scale ranging from [1] unsatisfied to [5] satisfied.

Two individual factors were also considered as control variables. First, organizational size is considered to influence employees' satisfaction, particularly satisfaction with the organization as an employer. As a proxy variable, number of employees (number of full-fledged employees, scored on a 7-point scale ranging from [1] fewer than 30 to [7] 10,000 or more) was therefore included. We also added years of employment (real numbers) as a control variable because satisfied employees are typically less likely to leave an employer. One can also assume that the longer employees continue to work for the employer, the more committed to and satisfied with the employer they are.

\subsection{Analytical Process}

Hierarchical regression analysis was used to test for main and moderating effects of measured variables. First, number of employees at the organization, years of employment, and annual income were compulsorily entered as control variables into the equation (model 1). WLB program comprehensiveness was then compulsorily added to the model to examine its effect on the dependent variables (model 2). Finally, the product of annual income and WLB program comprehensiveness was added to the model (model 3). Some past studies have found differences on the basis of gender in the effects of WLB programs on employee attitudes (Bergman \& Gardiner, 2007; Burgess, Henderson, \& Strachan, 2007; Doble \& Supriya, 2010; Emslie \& Hunt, 2009; Scandura \& Lankau, 1997). Therefore, the dataset was analyzed separately for male and female individuals to test for the effects of gender on the main and moderating effects of the variables.

\section{Results}

\subsection{Basic Statistics and Inter-correlations among Variables}

Table 1 shows the percentages of respondents whose employers have each of the WLB program types. Multiple employees in the same organization might have answered the questionnaire; thus, the percentages are properly 
understood as rates of employees, not rates of entire organizations, although we believe that these values may also, at least to some degree, reflect the current states of WLB programs in the organizations. As shown in Table 1, the most prevalent WLB program is "short-term leave with pay" (36.61\%), and the second-most-common is "sick leave (without pay)" (27.12\%). This tendency is natural, considering that such leave is necessary for almost every employee at some time, regardless of gender or age. "Reemployment of women who resigned because of child or nursing care" $(7.20 \%)$ and "replacement personnel in the event of childbirth and childcare leave" $(6.63 \%)$ were the least frequent WLB programs. Reemploying women and providing replacements in the event of leave are fundamental issues of human resource management (HRM) for employers, and it is considered difficult for most organizations to have such WLB programs because they also require basic changes in HRM strategy.

Insert Table 1 about here

Table 2 shows the means and standard deviations (std. dev.) of the variables. Table 2 also describes t-values examining the significance of differences between the mean values of variables for male and female employees. Female employees had significantly higher WLB satisfaction and job satisfaction than did male employees. In contrast, male employees worked with significantly higher mean numbers of other employees, had more years of employment, and had more annual income. WLB program comprehensiveness is also higher for male employees than for female employees, though the difference is only marginally significant $(p=.054)$. Employer satisfaction does not differ on the basis of gender.

\section{Insert Table 2 about here}

Table 3 displays the intercorrelations among the variables. Correlations to the lower left of the diagonal line are those of the male employees, and those to the upper right of the line are those of the female employees. For both samples, the number of employees working for the employer, the number of years of employment, and annual income were all significantly correlated with each other. All of the correlations between each pair of satisfaction measures were also significant. There were major differences between the male and female employees in terms of the correlations between years of employment or annual income and any of the three satisfaction measures. All six of the correlations were significant for the male employees, whereas none were significant for the female employees. This implies that employee satisfaction among women is less susceptible to such organizational or individual factors than is employee satisfaction among men.

Insert Table 3 about here

\subsection{Hypotheses Testing}

The results of the hierarchical regression analysis are shown in Tables 4, 5, and 6. The tables show non-standardized partial regression coefficients and their standard errors in each of the hierarchical regression models. The results of the male participants are shown on the left, and those of the female participants are shown on the right. Table 4 displays the results of the analysis with WLB satisfaction as a dependent variable. The satisfaction of male employees with their WLB is affected by annual income $(b=.081, \mathrm{p}<.001)$ and WLB program comprehensiveness $(\mathrm{b}=.026, \mathrm{p}<.005)$, even after correcting for interactions between variables. However, the interaction between annual income and WLB program comprehensiveness was not significant $(b=-.004$, n.s.), and there was no significant increase in the coefficient of determination under model $3\left(\Delta \mathrm{R}^{2}=.001\right.$, n.s. $)$. In contrast, for the female participants, neither the main effect of annual income $(b=-.015$, n.s.) nor of WLB program comprehensiveness $(b$ $=.009$, n.s. $)$ was significant, although the interaction between their effects on WLB satisfaction was significant $(\mathrm{b}=$ $0.014, \mathrm{p}<.005)$. The coefficient of determination also significantly increased from model 2 to model $3\left(\Delta \mathrm{R}^{2}=.004\right.$, $\mathrm{p}<.005)$. The hypotheses were differentially supported on the basis of gender: H1 was supported for male employees and $\mathrm{H} 2$ was supported for female employees.

Insert Table 4 about here

Table 5 shows the results using job satisfaction as a dependent variable. This table shows contrasting results between male and female employees. For the male employee sample, model 3 shows that the main effects of annual income $(\mathrm{b}=.078, \mathrm{p}<.01)$ and WLB program comprehensiveness $(\mathrm{b}=.033, \mathrm{p}<.01)$ on job satisfaction and the interaction between annual income and WLB program comprehensiveness $(b=.007, p<.1)$ are all significant. The increase in the coefficient of determination from model 2 to model 3 was marginally significant $\left(\Delta R^{2}=.002, p<.1\right)$. However, none of these effects was significant for the female employees. In fact, none of the variables entered into model 3 as independent variables had a significant effect on job satisfaction when considering the female employees alone. Therefore, both $\mathrm{H} 1$ and $\mathrm{H} 2$ were supported, but only for male employees.

Insert Table 5 about here 
Finally, the results of hierarchical regression analysis with employer satisfaction as a dependent variable are shown in Table 6. The main effects of annual income $(b=.107, p<.01)$ and WLB program comprehensiveness $(b=.046, p$ $<.01)$ and their interaction $(b=.012, p<.01)$ were all significant for the male employees. For the female employees, the main effect of annual income was not significant $(b=.002$, n.s.), but both program comprehensiveness $(b=.032$, $\mathrm{p}<.05)$ and the interaction between these two variables were significant $(b=.014, \mathrm{p}<.05)$. For both samples, there was a significant increase in the coefficient of determination $\left(\Delta \mathrm{R}^{2}=.006, \mathrm{p}<.01\right.$ for males; $\Delta \mathrm{R}^{2}=.004, \mathrm{p}<.05$ for females) between model 2 and model 3. Therefore, $\mathrm{H} 1$ and $\mathrm{H} 2$ were supported in both samples.

\section{Insert Table 6 about here}

Figure 2 illustrates the moderating effect of annual income $(\mathrm{Z})$ on the relationship between WLB program comprehensiveness $(\mathrm{X})$ and employer satisfaction $(\mathrm{Y})$ for male employees. From bottom, three lines display the relationships between $\mathrm{X}$ and $\mathrm{Y}$ according to low (mean minus 1 standard deviation), mean, and high values (mean plus 1 standard deviation) of $Z$, respectively. This figure shows that the effect of WLB program comprehensiveness on employer satisfaction is stronger when annual income is comparatively high relative to when it is comparatively low.

Insert Figure 2 about here

\section{Discussion and Conclusion}

The present work found not only a main effect of WLB program comprehensiveness on employee satisfaction but also a moderating effect of annual income on this relationship. First, the results of hierarchical regression analysis show that WLB program comprehensiveness causes different effects for male and female employees. In particular, the comprehensiveness of WLB programs has a significantly positive impact on all three satisfaction measures for male employees, but for female employees, the comprehensiveness of WLB programs has a significant relationship only with employer satisfaction. This implies that WLB program comprehensiveness has different implications for male and female employees.

In Japanese workplaces, WLB programs are utilized more by female employees than by male employees. Therefore, female employees might evaluate the quality of each of the WLB programs according to their own needs as though they are potential or actual users. As a result, they might not emphasize comprehensiveness. In contrast, male employees might not evaluate WLB programs as being able to solve their current problems in balancing work with life. In essence, male employees are not able to specify their concrete WLB needs. This may lead them to emphasize WLB program comprehensiveness as one of the criteria for evaluating WLB programs.

Although the present research provides further insights into the relationships between workplace WLB programs and employee satisfaction, several limitations need to be addressed in the future. First, some measures were simple and could be improved. For example, although simple items were used to measure employees' satisfaction, past studies have typically used several kinds of multi-item scales to measure employee attitudes toward jobs and organizations (Fields, 2002). Further, the simple measure we created that adds up the WLB programs that an organization offers needs to be refined in several ways. Given that some WLB programs are more important than others, it may be beneficial to use appropriately weighted criteria that account for these differences. Considering work availability and family availability for employees in different situations might be important in considering the benefits of each WLB program (Bergman \& Gardiner, 2007). Further, some employees are not eligible to use some WLB programs. Not only the presence but also the availability of WLB programs therefore needs to be taken into account. In addition, WLB programs may also be divided into several categories on the basis of functional differences. For example, according to Brough and O'Driscoll (2010), organizational interventions for WLB are divided into three main types: initiatives addressing working hours, collaborative action research focused on improving levels of workplace equity and performance, and initiatives to embed WLB associations.

Second, as with our hypothetical models, a fair percentage of the participating employees we investigated likely had spouses who also earned money. The availability of a WLB program might depend on whether or not the spouse has a job. Therefore, considering not only the employee's own income but also that of his or her family is also necessary in order to accurately assess employees' needs for WLB programs. For example, Eberharter (2001) used family income minus individual income as an independent variable representing how much money an employee's family has independent of the employee.

Third, this article does not address the effects of organizational social support on how employees recognize the WLB programs with which they are provided. Utilizing some programs, such as temporary leave and telecommuting, might be associated with supportive social relationships in the workplace (Ferguson, Carlson, Zivnuska, \& Whitten, 
2012). However, this might not be a simple problem because some research has failed to show a positive effect of social support on WLB initiatives (Smith, \& Gardner, 2007). Our understanding of how such social support effects can be modeled could also benefit from additional research.

Finally, our hypotheses were very general and did not include any consideration of specific labor situations in Japan. Most Japanese employers struggle between maintaining traditional familistic ideas and seeking more economic rationalistic views regarding employee management (Maanen, 2006). WLB comprehensiveness might become a symbol showing how important an organization considers its employees to be, but too many WLB programs probably have too little meaning to efficiently and effectively enhance employees' commitment and motivation to work. Future study could lend new insights to employers facing difficult employment problems regarding how many (and what types of) WLB programs are economically effective.

\section{Acknowledgement}

I really appreciate two referees' giving me useful comments regarding the first version of this paper.

\section{References}

Baard, N., \& Thomas, A. (2010). Teleworking in South Africa: Employee benefits and challenges. SA Journal of Human Resource Management, 8(1), 1-10.

Bailey, D. E., \& Kurland, N. B. (2002). A review of telework research: Findings, new directions, and lessons for the study of modern work. Journal of Organizational Behavior, 23, 383-400. http://dx.doi.org/10.1002/job.144

Baral, R., \& Bhargava, S. (2010). Work-family enrichment as a mediator between organizational interventions for work-life balance and job outcomes. Journal of Managerial Psychology, 25(3), 274-300. http://dx.doi.org/10.1108/02683941011023749

Beauregard, T. A., \& Henry, L. C. (2009). Making the link between work-life balance practices and organizational performance. Human Resource Management Review, 19(1), 9-22. http://dx.doi.org/10.1016/j.hrmr.2008.09.001

Bergman, A., \& Gardiner, J. (2007). Employee availability for work and family: Three Swedish case studies. Employees Relations, 29(4), 400-414. http://dx.doi.org/10.1108/01425450710759226

Brough, P., \& O'Driscoll, M. P. (2010). Organizational interventions for balancing work and home demands: An overview. Work \& Stress: An International Journal of Work, Health \& Organisation, 24, 280-297. http://dx.doi.org/10.1080/02678373.2010.506808

Burgess, J., Henderson, L., \& Strachan, G. (2007). Work and family balance through equal employment opportunity programmes and agreement making in Australia. Employee Relations, 29(4), 415-430. http://dx.doi.org/10.1108/01425450710759235

Ciutacu, C., Chivu, L., \& Hurley, J. (2008). Work-life balance in Romania: A comparative approach. Romanian Journal of Economics, 26, 64-77.

Cooke, G. B., Zeytinoglu, I. U., \& Mann, S. L. (2009). Weekend-based short workweeks: Peripheral work or facilitating 'work-life balance'? Community, Work \& Family. 12(4), 409-415. http://dx.doi.org/10.1080/13668800902753911

Doble, N., \& Supriya, M. V. (2010). Gender differences in the perception of work-life balance. Management, 5, 331-342.

Dore, R. (1979-1980). The internationalisation of Japan. Pacific Affairs, 52(4), 595-611. [Online] Available: http://www.jstor.org/stable/2757063.

Eberharter, V. V. (2001). Gender roles, labour market participation and household income position. Structural Change and Economic Dynamics, 12, 235-246. http://dx.doi.org/10.1016/S0954-349X(01)00021-2

Emslie, C., \& Hunt, K. (2009). 'Live to work' or 'work to live'? A qualitative study of gender and work-life balance among men and women in mid-life. Gender, Work and Organization, 16, 151-172. http://dx.doi.org/10.1111/j.1468-0432.2008.00434.x

Ferguson, M., Carlson, D., Zivnuska, S., \& Whitten, D. (2012). Support at work and home: The path to satisfaction through balance. Journal of Vocational Behavior, 80, 299-307. http://dx.doi.org/10.1016/j.jvb

Fields, D. L. (2001). Taking the measure of work: A guide to validated scales for organizational research and diagnosis. Thousand Oaks: Sage. 
Fujimoto, T. (2006). Preferences for working hours over life course among Japanese manufacturing workers. Career Development International, 11(3), 204-215. http://dx.doi.org/10.1108/13620430610661731

Golden, T. D. (2006). The role of relationships in understanding telecommuter satisfaction. Journal of Organizational Behavior, 27, 319-340. http://dx.doi.org/10.1002/job.369

Grandey, A. A., Cordeiro, B. L., \& Michael, J. H. (2007). Work-family supportiveness organizational perceptions: Important for the well-being of make blue-collar hourly workers? Journal of Vocational Behavior, 71, 460-478. http://dx.doi.org/10.1016/j.jvb.2007.08.001

Gropper, A., Gartle, K., \& MacLaren, M. (2010). Work-life programs for Canadian medical faculty. Journal of Women's Health, 19, 1683-1703. http://dx.doi.org/10.1089/jwh.2009.1809

Hilbrecht, M., Shaw, S. M., Johnson, L. C., \& Andrey, J. (2008). 'I'm home for the kids': Contradictory implications for work-life balance of teleworking mothers. Gender, Work and Organization, 15, 454-476. http://dx.doi.org/10.1111/j.1468-0432.2008.00413.x

Hill, E. J., Ferris, M., \& Martinson, V. (2003). Does it matter where you work? A comparison of how three work venues (traditional office, virtual office, and home office) influence aspects of work and personal/family life. Journal of Vocational Behavior, 63(2), 220-241.

Lambert, S. J. (2000). Added benefits: The link between work-life benefits and organizational citizenship behavior. Academy of Management Journal, 43, 801-815. [Online] Avaliable: http://www.jstor.org/stable/1556411

Maanen, J. V. (2006). Rediscovering Japan: Some thought on change and continuity in traditional Japanese careers. Career Development International, 11(4), 280-292. http://dx.doi.org/10.1108/13620430610672504

Matsuda, Y., Kokumai, M., \& Wang, J. (2009). Report on survey for work-life balance in Japanese companies (in Japanese). Okayama Economic Review, 41(2), 55-76.

Michel, J. S., Mitchelson, J. K., Kotrba, L. M., LeBreton, J. M., \& Baltes, B. B. (2009). A comparative test of work-family conflict models and critical examination of work-family linkages. Journal of Vocational Behavior, 74(2), 199-218. http://dx.doi.org/10.1016/j.jvb.2008.12.005

Money, R. B., \& Graham, J. L. (1999). Salesperson performance, pay, and job satisfaction: Tests of a model using data collected in the United States and Japan. Journal of International Business Studies, 30(1), 149-172. [Online] Avaliable: http://www.jstor.org/stable/155273

Muse, L., Harris, S. G., Giles, W. F., \& Feild, H. S. (2008). Work-life benefits and positive organizational behavior: Is there a connection? Journal of Organizational Behavior, 29, 171-192. http://dx.doi.org/10.1002/job.506

Scandura, T. A., \& Lankau, M. J. (1997). Relationship of gender, family responsibility and flexible hours to organizational commitment and job satisfaction. Journal of Organizational Behavior, 18, 377-391. http://dx.doi.org/10.1002/(SICI)1099-1379(199707)18:4<377::AID-JOB807>3.0.CO;2-1

Smith, J., \& Gardner, D. (2007). Factors affecting employee use of work-life balance initiatives. New Zealand Journal of Psychology, 36, 3-12.

Tytheirleigh, M. Y. (2003). What employers may learn from English higher education institutions: A fortigenic approach to occupational stress. SA Journal of Industrial Psychology, 29(4), 101-106.

Valcour, M., Ollier-Malaterre, A., Matz-Costa, C., Pitt-Catsouphes, \& Brown, M. (2011). Influences on employee perceptions of organizational work-life support: Signals and resources. Journal of Vocational Behavior, 79, 588-595. http://dx.doi.org/10.1016/j.jvb.2011.02.002 
Table 1. WLB Programs in the Organization

\begin{tabular}{lrr}
\hline \multicolumn{1}{c}{ WLB programs } & $\begin{array}{c}\text { no. of } \\
\text { persons }\end{array}$ & percent \\
\hline Childcare leave more than legally required period & 425 & $14.30 \%$ \\
Nursing care more than legally required period & 288 & $9.69 \%$ \\
Family care leave & 357 & $12.01 \%$ \\
Sick leave (with no pay) & 806 & $27.12 \%$ \\
Leave for short hours with pay & 1,088 & $36.61 \%$ \\
Late opening time or early closing time & 564 & $18.98 \%$ \\
Short-time work for child or nursing care & 413 & $13.90 \%$ \\
Flexible working time & 606 & $20.39 \%$ \\
Exemption of extra working hours & 227 & $7.64 \%$ \\
Telework & 223 & $7.50 \%$ \\
Re-employment of the person who resigned for child or nursing care & 214 & $7.20 \%$ \\
Inter-convertibility between employment formats like fulltime & 357 & $12.01 \%$ \\
and part-time employment & 279 & $9.39 \%$ \\
Work in a limited area with no need of job transfer & 197 & $6.63 \%$ \\
Backup personnel due to childbirth and childcare leave & 344 & $11.57 \%$ \\
Re-employment of women who retired due to pregnancy and childbirth & 2,972 & $100 \%$ \\
\hline Total & &
\end{tabular}

Table 2. Means and Standard Deviations (std. dev.) of Variables by Gender

\begin{tabular}{|c|c|c|c|c|c|c|c|c|}
\hline \multirow{2}{*}{ variables } & \multicolumn{3}{|c|}{ male } & \multicolumn{3}{|c|}{ female } & \multirow{2}{*}{ t-value } & \multirow{2}{*}{ sig } \\
\hline & means & std. dev. & $\mathrm{N}$ & means & std. dev. & $\mathrm{N}$ & & \\
\hline 1 Num. of employees & 3.211 & 1.911 & 1,675 & 2.704 & 1.761 & 1,297 & 7.497 & $<.001$ \\
\hline 2 Years of employment & 10.079 & 9.768 & 1,665 & 5.758 & 5.96 & 1,279 & 14.817 & $<.001$ \\
\hline 3 Annual income & 4.726 & 2.473 & 1,615 & 2.378 & 1.607 & 1,215 & 30.538 & $<.001$ \\
\hline $\begin{array}{l}\text { WLB program } \\
\text { comprehensiveness }\end{array}$ & 2.23 & 2.595 & 1,675 & 2.045 & 2.625 & 1,297 & 1.927 & 0.054 \\
\hline 5 WLB satisfaction & 2.717 & 1.098 & 1,660 & 2.893 & 1.075 & 1,290 & -4.374 & $<.001$ \\
\hline 6 Job satisfaction & 3.287 & 1.066 & 1,675 & 3.476 & 0.958 & 1,297 & -5.063 & $<.001$ \\
\hline 7 Employer satisfaction & 2.858 & 1.126 & 1,675 & 2.923 & 1.068 & 1,297 & -1.594 & 0.111 \\
\hline
\end{tabular}

Table 3. Intercorrelations among Variables

\begin{tabular}{|c|c|c|c|c|c|c|c|}
\hline variables & 1 & 2 & 3 & 4 & 5 & 6 & 7 \\
\hline 1 Num. of employees & 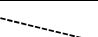 & $0.136^{* *}$ & $0.226^{* *}$ & $0.294^{* * *}$ & 0.028 & 0.007 & 0.037 \\
\hline 2 Years of employment & $0.317^{* 1+}$ & $\cdots$ & $0.466^{* *}$ & $0.192^{* *}$ & 0.023 & -0.003 & 0.006 \\
\hline 3 Annual income & $0.407^{* *}$ & $0.595^{*}$ & & $0.242^{* *}$ & 0.008 & 0.011 & 0.033 \\
\hline $4 \begin{array}{l}\text { WLB program } \\
\text { comprehensiveness }\end{array}$ & $0.339^{* *}$ & $0.224^{* * *}$ & $0.304^{* *}$ & & 0.039 & 0.028 & $0.094^{* *}$ \\
\hline 5 WLB satisfaction & 0.026 & $0.088^{* * *}$ & $0.163^{* *}$ & $0.082^{* *}$ & & $0.262^{* *}$ & $0.266^{* *}$ \\
\hline 6 Job satisfaction & 0.029 & $0.067^{* *}$ & $0.162^{* *}$ & $0.1^{* *}$ & $0.316^{* *}$ & & 0.501 ** \\
\hline 7 Employer satisfaction & $0.089^{* *}$ & $0.068^{* * *}$ & $0.213^{* *}$ & 0.155 & $0.333^{* *}$ & $0.553^{\text {** }}$ & \\
\hline
\end{tabular}


Table 4. Result of Hierarchical Regression Analysis with WLB Satisfaction as a Dependent Variable

WLB satisfaction (dependent variable)

\begin{tabular}{|c|c|c|c|c|c|c|}
\hline & \multicolumn{3}{|c|}{ Males } & \multicolumn{3}{|c|}{ Females } \\
\hline & model 1 & model 2 & model 3 & model 1 & model 2 & model 3 \\
\hline Constant & $2.408(.065)^{* * *}$ & $2.404(.065)^{* * *}$ & $2.395(.065)^{* * *}$ & $2.846(.068)^{* * *}$ & $2.842(.068)^{* * *}$ & $2.864(.069)^{* * *}$ \\
\hline Num. of employees & $-.025(.030)$ & $-.034(.016)^{* *}$ & $-.032(.016)^{* *}$ & $.017(.018)$ & $.012(.019)$ & $.009(.019)$ \\
\hline Years of employment & $-.001(.003)$ & $-.001(.003)$ & $-.001(.003)$ & $.004(.006)$ & $.003(.006)$ & $.002(.006)$ \\
\hline Annual income & $.083(.014)^{* * *}$ & $.079(.014)^{* * *}$ & $.081(.014)^{* * *}$ & $-.005(.022)$ & $-.008(.022)$ & $-.015(.023)$ \\
\hline $\begin{array}{l}\text { WLB program } \\
\text { comprehensiveness }\end{array}$ & & $.025(.011)^{* *}$ & $.026(.011)^{* *}$ & & $.013(.013)$ & $.009(.013)$ \\
\hline $\begin{array}{l}\text { Annual income } * \text { WLB } \\
\text { program comp. }\end{array}$ & & & $-.004(.004)$ & & & $.014(.007)^{* *}$ \\
\hline change in $\mathrm{R}^{2}$ & $0.029^{* * *}$ & $0.003^{* *}$ & 0.001 & 0.001 & 0.001 & $0.004^{* *}$ \\
\hline adjusted $\mathrm{R}^{2}$ & 0.027 & 0.029 & 0.029 & $<.001$ & $<.001$ & 0.001 \\
\hline
\end{tabular}

Table 5. Result of Hierarchical Regression Analysis with Job Satisfaction as a Dependent Variable

\begin{tabular}{|c|c|c|c|c|c|c|}
\hline & \multicolumn{6}{|c|}{ job satisfaction (dependent variable) } \\
\hline & \multicolumn{3}{|c|}{ Males } & \multicolumn{3}{|c|}{ Females } \\
\hline & model 1 & model 2 & model 3 & model 1 & model 2 & model 3 \\
\hline Constant & $2.996(.063)^{* * *}$ & $2.991(.063)^{* *}$ & $3.007(.063)^{* * *}$ & $3.495(.060)^{* * *}$ & $3.491(.060)^{* * *}$ & $3.498(.061)^{* * *}$ \\
\hline Num. of employees & $-.026(.015)^{*}$ & $-.039(.016)^{* *}$ & $-.042(.016)^{* * *}$ & $-.007(.016)$ & $-.013(.016)$ & $-.014(.016)$ \\
\hline Years of employment & $-.003(.003)$ & $-.003(.003)$ & $-.004(.003)$ & $-.003(.005)$ & $-.004(.005)$ & $-.004(.005)$ \\
\hline Annual income & $.087(.014)^{* * *}$ & $.081(.014)^{* * *}$ & $.078(.014)^{* * *}$ & $.012(.020)$ & $.008(.020)$ & $.006(.020)$ \\
\hline $\begin{array}{l}\text { WLB program } \\
\text { comprehensiveness }\end{array}$ & & $.034(.011)^{* * *}$ & $.033(.011)^{* * *}$ & & $.017(.011)$ & $.016(.011)$ \\
\hline $\begin{array}{l}\text { Annual income } * \text { WLB } \\
\text { program comp. }\end{array}$ & & & $.007(.004) *$ & & & $.005(.006)$ \\
\hline change in $\mathrm{R}^{2}$ & $0.03^{* * *}$ & $0.006^{* * *}$ & 0.002 * & 0.001 & 0.002 & 0.001 \\
\hline adjusted $\mathrm{R}^{2}$ & 0.028 & 0.033 & 0.035 & $<.001$ & $<.001$ & $<.001$ \\
\hline
\end{tabular}

Table 6. Result of Hierarchical Regression Analysis with Organization Satisfaction as a Dependent Variable

\begin{tabular}{|c|c|c|c|c|c|c|}
\hline & \multicolumn{6}{|c|}{ employer satisfaction (dependent variable) } \\
\hline & \multicolumn{3}{|c|}{ Males } & \multicolumn{3}{|c|}{ Females } \\
\hline & model 1 & model 2 & model 3 & model 1 & model 2 & model 3 \\
\hline Constant & $2.363(.066)^{* * *}$ & $2.357(.065)^{* * *}$ & $2.383(.066) * * *$ & $2.840(.067)^{* * *}$ & $2.830(.067)^{* * *}$ & $2.863(.068)^{* * *}$ \\
\hline Num. of employees & $.008(.016)$ & $-.010(.016)$ & $-.014(.016)$ & $.019(.018)$ & $.006(.018)$ & $.002(.018)$ \\
\hline Years of employment & $-.010(.004)^{* * *}$ & $-.011(.003)^{* * *}$ & $-.011(.003)^{* * *}$ & $-.001(.006)$ & $-.003(.006)$ & $-.004(.006)$ \\
\hline Annual income & $.121(.014)^{* * *}$ & $.112(.015)^{* * *}$ & $.107(.015)^{* * *}$ & $.016(.022)$ & $.022(.013)$ & $.002(.022)$ \\
\hline $\begin{array}{l}\text { WLB program } \\
\text { comprehensiveness }\end{array}$ & & $.049(.011)^{* * *}$ & $.046(.012)^{* * *}$ & & $.036(.013)^{* * *}$ & $.032(.013)^{* *}$ \\
\hline $\begin{array}{l}\text { Annual income } * \text { WLB } \\
\text { program comp. }\end{array}$ & & & $.012(.004)^{* * *}$ & & & $.014(.007) * *$ \\
\hline change in $\mathrm{R}^{2}$ & $0.052^{* * *}$ & $0.01^{* * *}$ & $0.006^{* * *}$ & 0.002 & $0.007^{* * *}$ & $0.004^{* *}$ \\
\hline adjusted $\mathrm{R}^{2}$ & 0.05 & 0.06 & 0.065 & $<.001$ & 0.005 & 0.008 \\
\hline
\end{tabular}




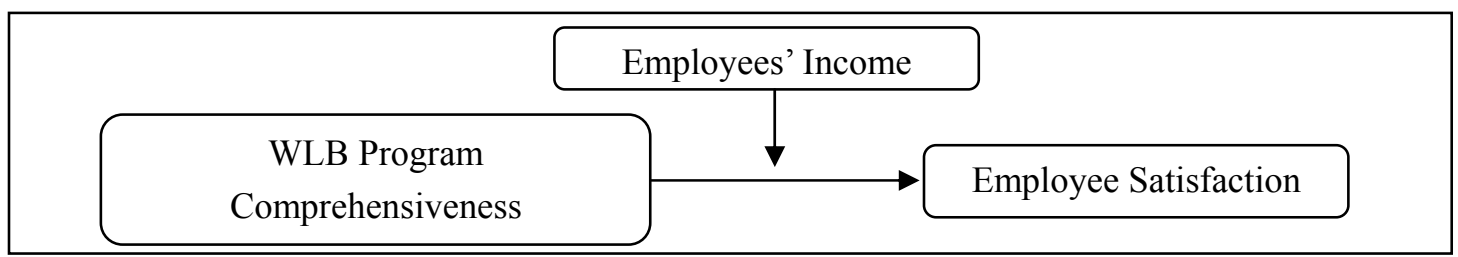

Figure 1. Hypothetical Framework for WLB Program Fullness, Employee Satisfaction and Income

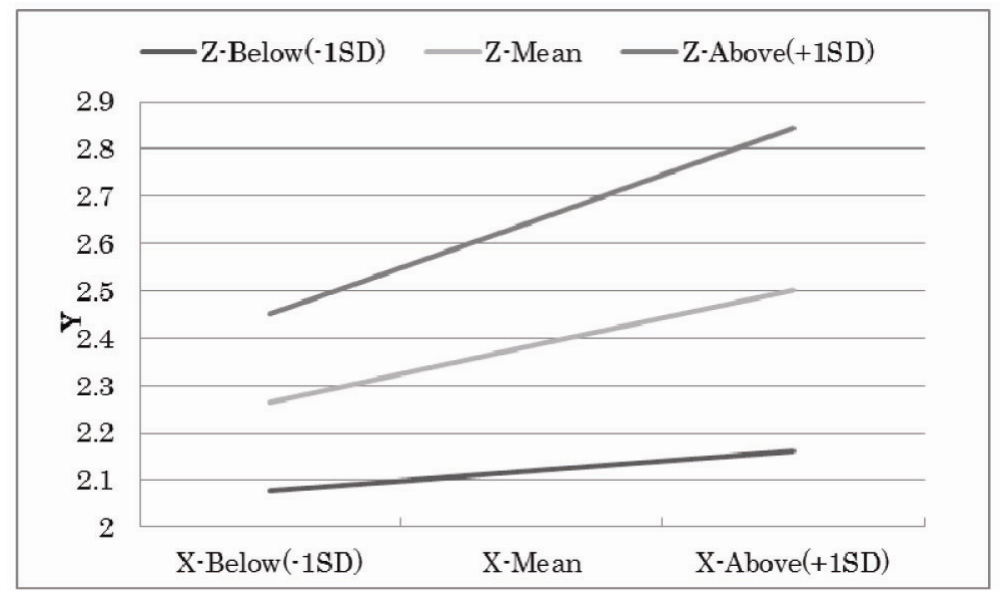

Figure 2. Moderating Effect of Annual Income (Z) on the WLB program comprehensiveness (X) and Employer Satisfaction (Y) Relationship for Make Employees 